\title{
Litter Production and Accumulation as an Indicator of Degradation in Caatinga
}

\author{
Ane Cristine Fortes da Silva ${ }^{1}$, César Henrique Alves Borges ${ }^{2}$, Camila Costa da Nóbrega ${ }^{3}$, \\ Patrícia Carneiro Souto ${ }^{4}$, Jacob Silva Souto ${ }^{4} \&$ José Augusto da Silva Santana ${ }^{5}$ \\ ${ }^{1}$ Federal Institute of Education, Science and Technology of Paraíba, Princesa Isabel, Brazil \\ ${ }^{2}$ Department of Forest Science, Federal Rural University of Pernambuco, Recife, Brazil \\ ${ }^{3}$ Department of Soils and Rural Engineering, Federal University of Paraíba, Areia, Brazil \\ ${ }^{4}$ Department of Forestry Science, Federal University of Campina Grande, Patos, Brazil \\ ${ }^{5}$ Department of Forestry Science, Federal University of Rio Grande do Norte, Natal, Brazil \\ Correspondence: César Henrique Alves Borges, Department of Forest Science, Federal Rural University of \\ Pernambuco, Recife, PE, Brazil. Tel: 55-849-9690-6392. E-mail: cesarhenrique27@yahoo.com.br
}

Received: December 13, 2018

Accepted: January 27, 2019 Online Published: August 15, 2019

doi:10.5539/jas.v11n13p134

URL: https://doi.org/10.5539/jas.v11n13p134

\begin{abstract}
The ecosystem processes in the caatinga, such as litter dynamic, are threatened and little is known about it in these environments. The litter processes can be used as indicators of degradation or recovery of an ecosystem because these processes react to changes in the ecosystems. The litterfall deposition was collected monthly over 23 months in collectors of $1.0 \mathrm{~m}^{2}$. The litter accumulation on soil was collected monthly over 23 months in frames of $0.25 \mathrm{~m}^{2}$. The coefficient of decomposition $(\mathrm{K})$ was estimated by the relation between annual litter production and litter stock in the soil surface. Annual litterfall production increased with stand age. Total annual litter production in different age stands varies from $1.37 \mathrm{Mg} \mathrm{ha}^{-1}$ in the 15 years to $2.37 \mathrm{Mg} \mathrm{ha}^{-1}$ in the 50 years stand. $\mathrm{K}$ and renewal times were also significantly different among the sites. $\mathrm{K}$ was higher in 50 years, followed by 30 years and 15 years. There were a higher litter production and accumulation in the older stands. The older stands presented faster litter decomposition and renew, which evidences a better utilization of litter in the nutrient cycling process and the incorporation of organic matter into the soil. These results show that litter processes are effective indicators of the stage of degradation in a caatinga ecosystem.
\end{abstract}

Keywords: litterfall, ecosystem processes, coefficient of decomposition, dry environments, forest degradation

\section{Introduction}

Over the last few centuries, the caatinga ecosystems are being degraded by human activities. The original vegetation covered close to 1.0 million hectares and nowadays only about $40 \%$ still remain as native vegetation (Gariglio et al., 2009). However, the most part of this remnant is explored for the wood extraction, pasture for breeding cattle, goats, and sheep or in the itinerant agriculture.

The ecosystem processes in the caatinga are threatened and little is known about it in these environments. The nutrients cycling is one of the ecosystem process more sensitive to these disturbances. The nutrients cycling is one of the determining functions for regulating the functioning and development of ecosystems (Santana \& Souto, 2011).

Most of the process of return of the mineral elements to the forest soil occurs through the production, accumulation, decomposition and release of the nutrients of the litter (Andrade et al., 2008). The litter layer is composed by vegetal origin tissues such as leaves, branches, seeds, fruits, flowers and animal origin, such as carcasses and excretas, in several decomposition states that accumulate on the soil serving as source of energy and nutrients for decomposing organisms.

The litterfall production and accumulation can be influenced by several abiotic and biotic factors, such as vegetation type, altitude, precipitation, temperature, lightness regimes, water stress, soil type, soil biota, vegetation structure and composition (Holanda et al., 2017). The environmental physical and chemical conditions, the heterotrophic activity of the decomposers and the quality and quantity of the organic residues 
resources will condition the time of the decomposition process (Cunha-Santino \& Bianchini Junior, 2002). Thus, the production, accumulation and decomposition of litter can be used as indicators of degradation or recovery of an ecosystem, because these processes reacts to changes in the ecosystems (Nascimento et al., 2015).

In the Caatinga, there are few studies about ecosystem processes that involve the dynamics of the litter (Souto, 2006; Costa et al., 2007; Lopes et al., 2009; Santana \& Souto, 2011; Holanda et al., 2017), particularly in degraded environments (Bauer et al., 2016; Luna et al., 2017). Moreover, there is few information about the use of the litter processes as indicators of degradation in caatinga. However, the existing studies cover short periods, which is not able to fully capture the behavior of these processes in face of the usual climatic oscillation among years in this region.

The gathering of information about the litter dynamic processes enables the understanding of the functioning of the caatinga ecosystems, seeking information for the establishment of forest management practices for the recovery of degraded areas and maintaining the productivity of degraded environments.

Our study examined litter production and accumulation processes in increasingly common regenerated caatinga. The following specific hypotheses were tested: (1) litterfall mass production and accumulation on the soil increase with the regeneration age; (2) litterfall mass production, accumulation on the soil and decomposition coefficient are efficient indicators of degradation in caatinga ecosystems. Therefore, the objective of our study was to evaluate the litter production and accumulation as an indicator of degradation of the caatinga vegetation.

\section{Method}

\subsection{Study Area}

The study was conducted in a Caatinga dry forest fragment located in Paraiba State, north east of Brazil $\left(06^{\circ} 48^{\prime}\right.$ $\mathrm{S}$ e $36^{\circ} 57^{\prime} \mathrm{W}$ ). The area is characterized by semiarid climate, BSh' Köeppen's classification (Alvares et al., 2013). Mean annual temperature is $28{ }^{\circ} \mathrm{C}$ and mean annual precipitation is $700 \mathrm{~mm}$ (Paraíba, 2006). The dry period extends between seven and tem months. Topography is relatively flat reaching a mean elevation of $270 \mathrm{~m}$ above sea level.

The data of pluvial precipitation (monthly average values) were provided by the Agencia Estadual de Aguas da Paraiba. The total rainfall in the study period was $1,099.7 \mathrm{~mm}$. The highest values were recorded in the months of April/2011 (244 mm) and May/2011 (185.1 mm) and lowest values, in the months of June/2011 (3.8 $\mathrm{mm})$ and March/2012 (4 mm). During the period of this study, six months no rainfall were recorded October/2010, September/2011, November/2011, December/2011, April/2012 and July/2012 (Figure 1).

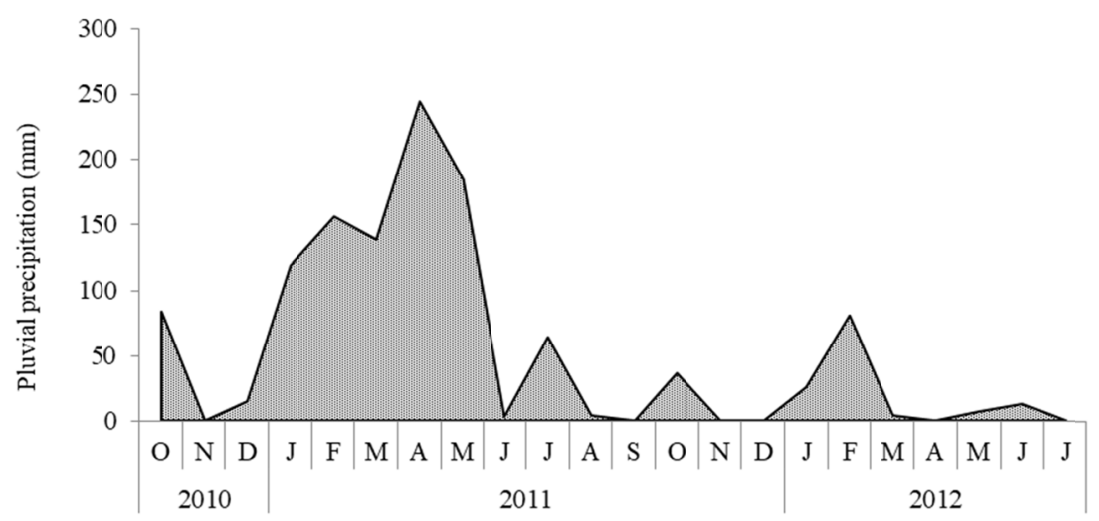

Figure 1. Pluvial precipitation data for the study area. Data were collected from the Agencia Estadual de Gestao das Aguas do Estado da Paraiba, Brazil

The soils of the study sites are of crystalline origin, whose chemical attributes are presented in Table 1. Soils of the sites are shallow and stony and belong to luvisols and leptosols (IUSS Working Group WRB, 2006). The vegetation of the sites shows different intensities of anthropism with trees of medium to low size not exceeding 8.0 meters in height. The historical use of land demonstrates that the natural tree-shrub Caatinga was replaced for the implementation of agricultural crops, mainly by the cultivation of cotton, and later, for grazing of goats and cattle. After that, the sites were abandoned and the forest regrowth. Some information of the vegetation characteristics are shown in Table 1. 
Table 1. Location, vegetation characteristics and soil chemical properties (in the $0-20 \mathrm{~cm}$ layer) in the study sites

\begin{tabular}{|c|c|c|c|}
\hline Site & 15 years old & 30 years old & 50 years old \\
\hline Location & $6^{\circ} 48^{\prime} 24^{\prime \prime} \mathrm{S}-36^{\circ} 57^{\prime} 10^{\prime \prime} \mathrm{W}$ & $6^{\circ} 48^{\prime} 22^{\prime \prime} \mathrm{S}-36^{\circ} 57^{\prime} 04^{\prime \prime} \mathrm{W}$ & $6^{\circ} 48^{\prime} 32^{\prime \prime} \mathrm{S}-36^{\circ} 57^{\prime} 09^{\prime \prime} \mathrm{W}$ \\
\hline Tree density $^{1}{ }_{(\mathrm{n} / \mathrm{ha})}$ & 173 & 466 & 986 \\
\hline Basal area ${ }^{1}\left(\mathrm{~m}^{2} / \mathrm{ha}\right)$ & 0.215 & 0.327 & 1.159 \\
\hline \multicolumn{4}{|l|}{ Soil parameters } \\
\hline $\mathrm{pH}{ }_{(\mathrm{CaCl} 2)}$ & 5.3 & 5.0 & 5.4 \\
\hline $\mathrm{OM}_{\left.(\mathrm{g} / \mathrm{dm})^{3}\right)}$ & 7 & 8 & 7 \\
\hline$P_{\text {resin }\left(g / \mathrm{dm}^{3}\right)}$ & 3 & 3 & 4 \\
\hline $\mathrm{Al}^{+3}\left(\mathrm{mmol} / \mathrm{dm}^{3}\right)$ & 1 & 1 & 1 \\
\hline $\left.\mathrm{H}+\mathrm{Al}_{(\mathrm{mmol} / \mathrm{dm}}{ }^{3}\right)$ & 15 & 18 & 15 \\
\hline $\mathrm{K}_{\left(\mathrm{mmol} / \mathrm{dm}^{3}\right)}$ & 3.8 & 2.3 & 1.6 \\
\hline $\mathrm{Ca}\left(\mathrm{mmol} / \mathrm{dm}^{3}\right)$ & 16 & 14 & 13 \\
\hline $\mathrm{Mg}_{\left(\mathrm{mmol} / \mathrm{dm}^{3}\right)}$ & 5 & 4 & 5 \\
\hline $\mathrm{CEC}_{(\mathrm{mmol} / \mathrm{dm})^{3}}$ & 39 & 38 & 34 \\
\hline
\end{tabular}

Note. ${ }^{1}$ Alencar (2014).

At the study area, sites were surrounded at different times to prevent the entry of cattle and goats and allow for the natural regeneration of the vegetation. Based on these regeneration times of the vegetation in the place, three different stands with dimensions of $6,600 \mathrm{~m}^{2}$ were selected to this study including a newly fenced area, a 15 years of regeneration area, a 30 years of regeneration area and an area with more than 50 years of regeneration.

The stand with 15 years of regeneration has about 15 years of fallow. This plot is characterized by the presence of fast-growing species mainly Croton blanchetianus Baill (marmeleiro), Cnidosculus quercifolius Pohl (favela), Poincianella pyramidalis (Tul.) L. P. Queiroz (catingueira), Mimosa tenuiflora (jurema preta), Aspidosderma pyrifolium Mart. (pereiro) and Combretum leprosum Mart. (mofumbo) (Alencar, 2014). These species develops after the clear cutting of vegetation in most part of Seridó region in Brazil north east.

The stand with 30 years of regeneration presents 30 years of fallow. This vegetation is predominantly composed of shrub-tree species of medium and small size, with clearings occupied by herbaceous species. Dominant overstory tree species include Croton blanchetianus Baill (marmeleiro), Cnidosculus quercifolius Pohl (favela), Poincianella pyramidalis (Tul.) L. P. Queiroz (catingueira) and Luetzelburgia auriculata (Allemão) Ducke (pau pedra). Common understory herbs include Diodella teres and Cyperus odorathus (Alencar, 2014).

The 50 years of regeneration stand has a vegetation more advanced stage constituting a higher floristic diversity and significant volume of wood trees. It presents a relatively uniform canopy with most of the crowns touching, shading the soil with consequent diminution of the herbaceous stratum. Dominant overstory tree species include Croton blanchetianus Baill (marmeleiro), Cnidosculus quercifolius Pohl (favela), Jatropha molissima (Pohl) Baill. (pinhão-bravo), Poincianella pyramidalis (Tul.) L.P. Queiroz (catingueira), Mimosa tenuiflora (Willd.) Poir. (jurema preta) and Bauhinia cheilantha (Bong.) Steud. (mororó) (Alencar, 2014).

\subsection{Litterfall Production}

For each selected stand, we established three $1000 \mathrm{~m}^{2}$ plots, within which all measurements were obtained. In each plot, eight litter traps were randomly placed on August/2010. A total of 24 litter traps were placed in each stand, totalizing 72 litter traps (8 litter traps $\times 3$ plots $\times 3$ stands).

All litter traps were made of collector made from iron bars and nylon mesh netting $\left(1 \mathrm{~mm}^{2}\right)$ and set about $25 \mathrm{~cm}$ above ground level. All the litterfall in each trap was emptied monthly over a period of 23 months, from September 2010 to July 2012. All litter from each trap was separated monthly into four different fractions: leaves, branches/twigs, reproductive structures (flowers, fruits and seeds) and others (which included plant and animal remains and unrecognizable fragments).

In the laboratory, the materials were packed in paper bags and submitted to forced circulation at $65{ }^{\circ} \mathrm{C}$ for $72 \mathrm{~h}$. Each fraction was weighed separately on a $0.01 \mathrm{~g}$ high precision digital scale to determine its contribution to total litterfall. The total production was obtained through the sum of the four fractions, which represents the monthly production of litter per litter trap. The annual production of litterfall was obtained through the sum of the monthly production of the collectors and was recorded in $\mathrm{Mg}$ ha $^{-1} \mathrm{year}^{-1}$. 


\subsection{Accumulation of Litter on the Ground}

For each selected stand, we established three $1000 \mathrm{~m}^{2}$ plots, within which all measurements were obtained. All organic material was removed from $0.25 \mathrm{~m}^{2}$ areas. Six replicates were randomly collected in each plot using an iron frame. A total of 18 collections were realized in each stand, totalizing 54 accumulated litter on the ground collections ( 6 litter traps $\times 3$ plots $\times 3$ stands).

The accumulated litter on the ground was estimated in all stands through monthly collections, over 23 months from September/2010 to July/2012, including the dry period and the rainy season. The litter was placed paper bags and dried at $65{ }^{\circ} \mathrm{C}$ to constant weight and was weighed separately on a $0.01 \mathrm{~g}$ high precision digital scale. The annual accumulated litter on the ground was obtained through the sum of the monthly production of the collectors and was recorded in $\mathrm{Mg} \mathrm{ha}^{-1}$ year $^{-1}$.

\subsection{Coefficient of Decomposition and Mean Time of Litter Renovation}

The coefficient of decomposition $(\mathrm{K})$ is an estimate of the proportion of decomposition of litter layer accumulated on the soil in one year. The coefficient of decomposition of litter was estimated by the equation proposed by Olson (1963):

$$
K=L / X s s
$$

In which: $\mathrm{K}=$ coefficient of decomposition; $\mathrm{L}=$ annual litter production in collectors $\left(\mathrm{Mg} \mathrm{ha}^{-1}\right)$;

Xss $=$ annual average of accumulated litter on the ground $\left(\mathrm{Mg} \mathrm{ha}^{-1}\right)$.

The $\mathrm{K}$ value or instantaneous decomposition coefficient is the ratio of litterfall produced/accumulated litter mass (Anderson \& Ingram, 1989). From the value of $\mathrm{K}$, the average renewal time estimated by $1 / \mathrm{K}$ and the time required for decomposition of $50 \%\left(\mathrm{t}_{50 \%}\right)$ and $95 \%\left(\mathrm{t}_{95 \%}\right)$ of the litter, estimated by the equation of Shanks and Olson (1961):

$$
\begin{gathered}
\mathrm{T}_{50 \%}=0.693 / \mathrm{K} \\
\mathrm{T}_{95 \%}=3 / \mathrm{K}
\end{gathered}
$$

\subsection{Data Analysis}

Exploratory testings were carried out to verify the compliance with the assumptions of normality, homoscedasticity and independence of data. The Shapiro-Wilk test was performed to verify the normality of the data and the Levene test was used to verify homoscedasticity. The one-way ANOVA was used to examine differences among stands. A repeated-measures analysis of variance was used. Tukey tests were performed to test differences among factors when $\mathrm{F}$-values were significant $(\mathrm{p}<0.05)$.

\section{Results}

Annual litterfall production increased with stand age. Total annual litter production in the different age stands of Caatinga regeneration varies from $1.37 \mathrm{Mg} \mathrm{ha}^{-1}$ in the 15 years of regeneration area to $2.37 \mathrm{Mg} \mathrm{ha}^{-1}$ in the 50 years of regeneration stand. ANOVA indicated a significant effect of site age to total litter production (Figure 2).

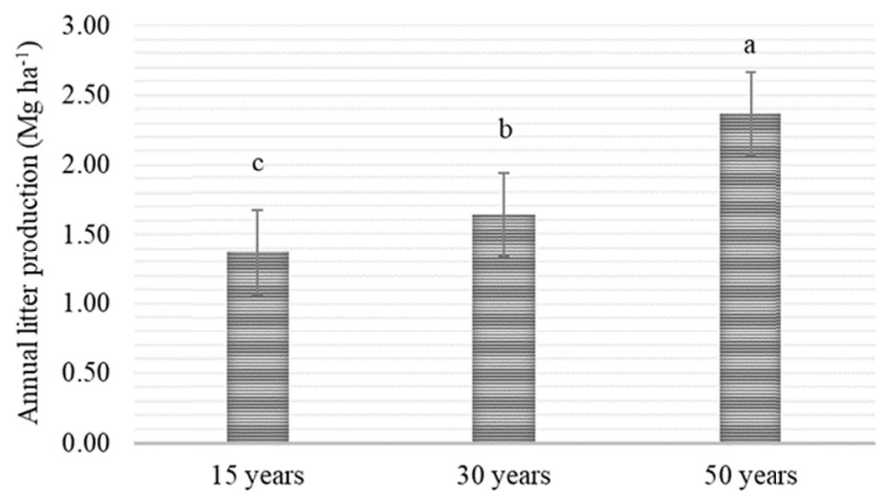

Figure 2. Annual litter production for different age stands. Standard deviations are indicated with error bars

Leaves constituted more than 72 percent of litterfall in all stands (Table 2). After the leaves, the highest proportions were observed for branches and twigs and reproductive components in the 30 years old stand. The opposite order was observed in the 15- and 50-years old stands (Table 2). 
The contribution of reproductive structures litter ranges between 8 and 19\%, while the others litter fraction do not produce much more than $2 \%$ of the total in each of the stands (Table 2 ).

The highest proportions of others fraction was observed for the 30 years stand, while the 15 years stand showed the lowest contribution (Table 2).

Table 2. Percentages of different components of litterfall in Caatinga vegetation sites, Brazil

\begin{tabular}{lllll}
\hline Site & Leaves $(\%)$ & Branches/Twigs $(\%)$ & Reproductive structures $(\%)$ & Others $(\%)$ \\
\hline 15 years & $76.64\left(19.25^{1}\right) \mathrm{c}$ & $10.95(5.11) \mathrm{b}$ & $11.68(5.14) \mathrm{b}$ & $1.46(0.85) \mathrm{c}$ \\
30 years & $72.56(18.44) \mathrm{b}$ & $16.46(7.33) \mathrm{a}$ & $8.54(3.87) \mathrm{b}$ & $2.44(0.98) \mathrm{a}$ \\
50 years & $72.15(18.33) \mathrm{a}$ & $6.75(3.25) \mathrm{b}$ & $18.99(7.38) \mathrm{a}$ & $2.11(0.96) \mathrm{b}$ \\
\hline
\end{tabular}

Note. ${ }^{1}$ Numbers in parentheses are the standard deviation of the mean.

Annual litterfall dry mass production in the stands showed peaks of distribution September 2010, between March and September 2011 and May 2012 in all stands. Total litterfall collected between March and September 2011 accounted for a large proportion (52-54 \%) of annual litterfall (Figure 3).

The highest productions were in April 2011 in the 15 and 30 years old stands $\left(0.33\right.$ and $0.39 \mathrm{Mg} \mathrm{ha}{ }^{-1}$, respectively). In the 50 years stand, the highest production was in May $2012\left(0.40 \mathrm{Mg} \mathrm{ha}^{-1}\right)$ (Figure 3).

Peaks in annual litterfall production of leaves followed a trend similar to that of total litter production (Figure 4). Annual branches and twigs litterfall dry mass production in all stands showed a bimodal distribution (April to May 2011 and 2012).

Annual reproductive structures dry mass production in 15- and 30-years old stands exposed a bimodal distribution (March to April 2011 and May 2012), while the 50-years old stand showed a extended bimodal peak pattern (February to June 2011 and May 2012) (Figure 4).

The fraction others presented a variable distribution with smaller productions during the months of August 2011 to June 2012 (Figure 4). The others fraction presented the lowest participation in the experimental areas, reaching a higher production in September 2010 in the 15-years stand, April 2011 in the 30 years and in November 2010 in 50 years stand (Figure 4).

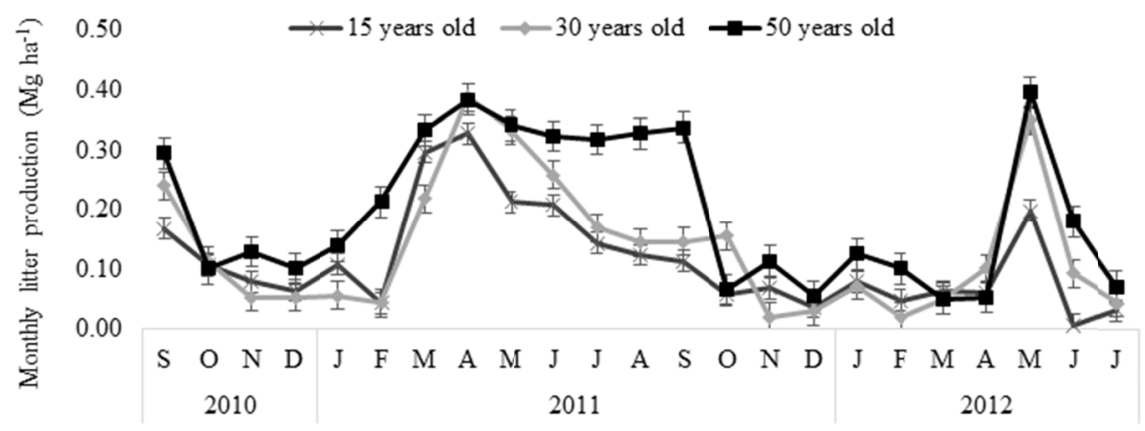

Figure 3. Monthly total deposition of litter for the different regeneration stands ages. Standard deviations are indicated with error bars

The mean value of the litter accumulated on the ground also increased with stand age. Mean annual litter accumulation in the different age stands fluctuates from $3.66 \mathrm{Mg} \mathrm{ha}^{-1}$ in the 15 years to $3.88 \mathrm{Mg} \mathrm{ha}^{-1}$ in the 50 years of regeneration stand. The 30 years stand showed a mean value of litter accumulation of $3.71 \mathrm{Mg} \mathrm{ha}^{-1}$. ANOVA no indicated a significant effect of site age to mean litter accumulation.

The coefficient of decomposition and renewal times were also significantly different among the sites $(\mathrm{p}<0.05)$. $\mathrm{K}$ was higher in 50 years, followed by 30 years and 15 years (Table 3 ). Due to the higher observed $\mathrm{K}$ in the 50 years stand, the renewal times in the 15- and 30-years sites were significantly higher than in 50 years stand (Table 3).

The mean time required for the litter renewal $(1 / \mathrm{K})$ was less than one year in the 50 years stand. The mean time 
required for the litter renewal, for the $50 \%$ and $95 \%$ decomposition decrease with the time of regeneration (Table $3)$.

Table 3. Decomposition coefficient $(\mathrm{K})$, average time of renovation $(1 / \mathrm{K})$ and necessary time for $50 \%\left(\mathrm{t}_{50 \%}\right)$ and at $95 \%\left(\mathrm{t}_{95 \%}\right)$ litter decomposition for the different stands ages

\begin{tabular}{llll}
\hline & 15 years & 30 years & 50 years \\
\hline $\mathrm{K}$ & $0.72 \mathrm{c}$ & $0.85 \mathrm{~b}$ & $1.17 \mathrm{a}$ \\
$1 / \mathrm{K}$ (years) & $1.39(507$ days $)$ & $1.18(430$ days $)$ & 0.85 (311 days) \\
$\mathrm{t}_{50 \%}$ (years) & $0.96(351$ days $)$ & $0.82(298$ days $)$ & 0.59 (216 days $)$ \\
$\mathrm{t}_{95 \%}$ (years) & $4.17(1521$ days $)$ & 3.54 (1291 days $)$ & 2.56 (935 days) \\
\hline
\end{tabular}

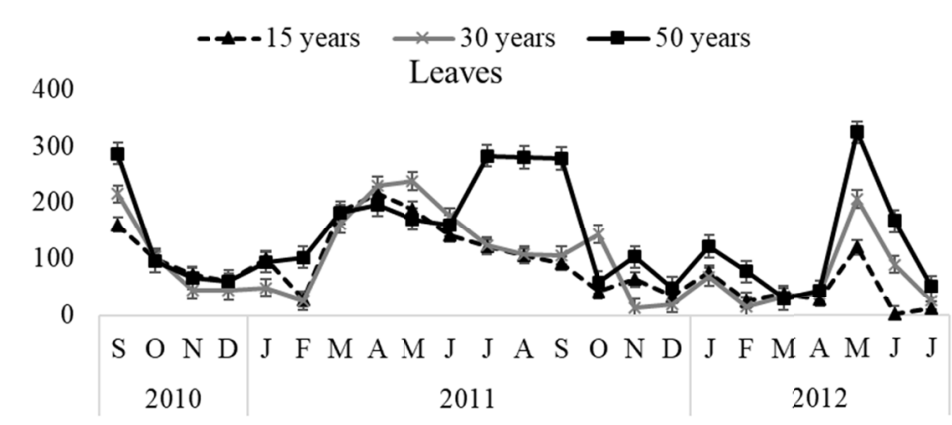

Branches/Twigs
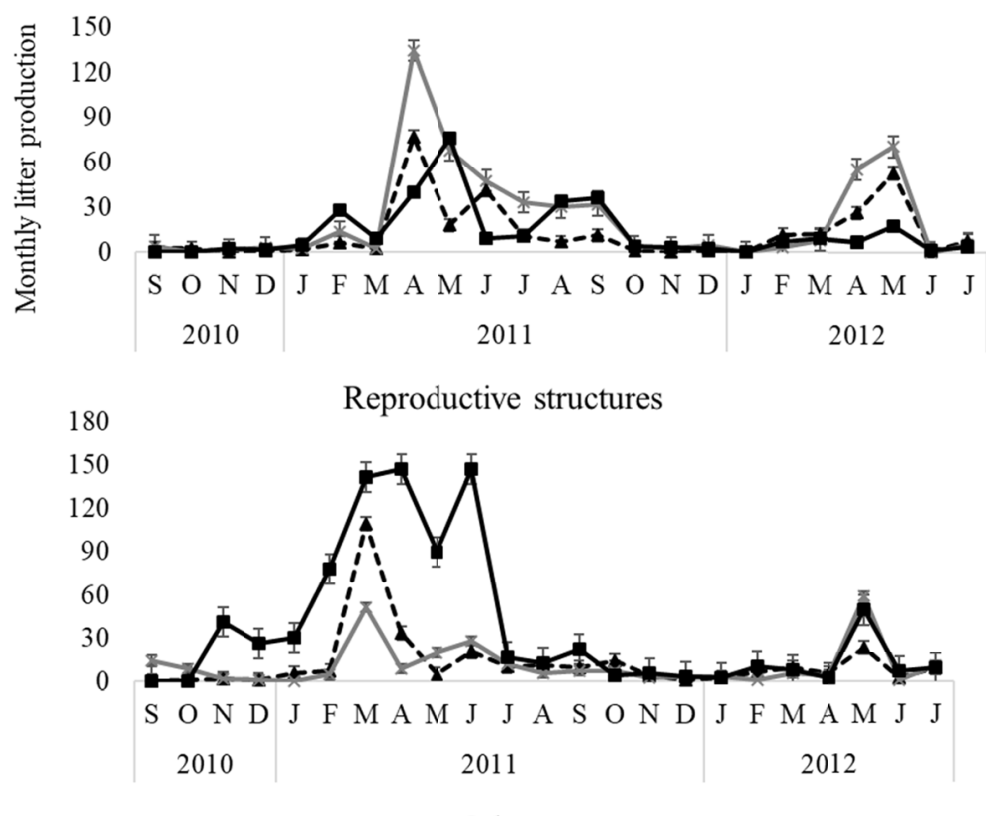

Others

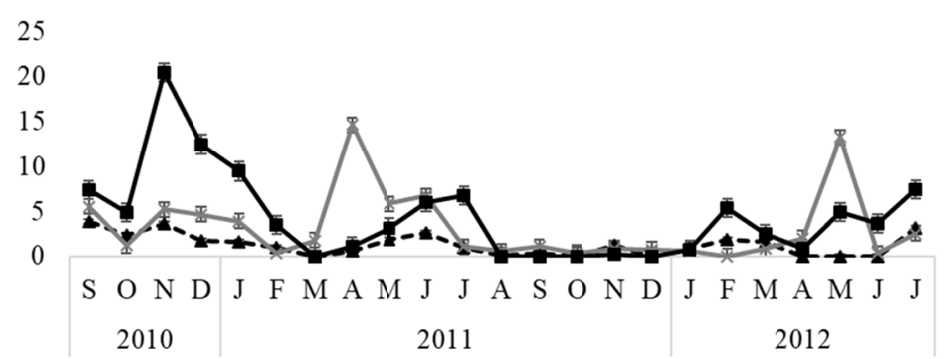

Figure 4. Monthly fractions deposition of litter $\left(\mathrm{Mg} \mathrm{ha}^{-1}\right)$ for the different regeneration stands ages. Standard deviations are indicated with error bars 


\section{Discussion}

Litterfall production was significantly influenced by the time of regenaration $(\mathrm{p}<0.01)$, where considerably lower litterfall was observed in 15 years old stand compared to 30 and 50 years old stands (Figure 2).

The low tree density can be the reason of the low productions in the young stands (Table 1). Almeida et al. (2015) affirm that areas with low tree density have simpler vertical and horizontal vegetation structure, influencing ecosystem processes such as litter production. The higher litterfall in the 50 years regeneration stand compared to the others stand has corroborated our hypotheses that higher litterfall would be observed in the older stand due to their higher biomass and closed canopy.

The litterfall fractions distribution pattern at the 30-year stand was similar to that found by Alves et al. (2006) and Andrade et al. (2008) in Caatinga fragments: leaves $>$ branches/twigs $>$ reproductive structures $>$ others. While Lopes et al. (2009) obtained a distribution similar to the stands of 15 and 50 years: leaves $>$ reproductive structures $>$ branches/twigs $>$ others.

The leaves contribution for the litterfall in the stands are close to the production average found in dry tropical forest environments. Martínez-Yrízar (1995) indicates that the leaf litter contributes typically around $70 \%$ of the total for dry tropical forests.

The leaf litter contributions range between 56.16 and $80.62 \%$ in Caatinga forest in different preservation levels (Alves et al., 2006; Souto, 2006; Costa et al., 2007; Andrade et al., 2008; Lopes et al., 2009; Santana \& Souto, 2011).

The highest deposition $\left(0.27 \mathrm{Mg} \mathrm{ha}^{-1}\right)$ was in the 30 years stand, where it was the second largest contribution in the total litter. In younger regeneration areas, tree vegetation is distributed more widely with large gaps between the shrubs, which facilitates wind movement. The mechanical action of these air masses together with the rain on the dry structures favors the deposition of the branches and twigs (Almeida et al., 2015).

Regarding the reproductive structures, we verified that this fraction was the second largest deposited in the 15 and 50 years stands. However, there was a significant difference between the stands with the highest litter production of this fraction in the older stand. This low production of reproductive structures in the younger stands can be explained by the floristic composition of these areas. In the younger stands, there is the predominance of pioneer species characterized by lighter and smaller fruits and seeds, such as marmeleiro and jurema preta, which, despite high yields, do not present a significant mass, as is the case with the fruits of the pereiro species, common in older stand, a fact confirmed during the litter screening.

Considerable seasonality in litterfall was demonstrated for all stands ages under study. The leaves showed a dinamic of production over the months similar to the total production. The branches and twigs fraction do not have a defined phenological pattern capable of being related to biotic and abiotic factors that can characterize the vegetation (Leitão-Filho et al., 1993). This fraction was the most variable with coefficient of variation higher than $40 \%$.

The reproductive structures dry mass production were higher in wet season in all stands. Similar results were obtained by Souto (2006) and Santana and Souto (2011). These authors affirm that practically the entire cycle of flowering and fruiting of the caatingas's species occurs after the beginning of the rainy season.

The others fraction showed low production during the dry season in all stands. Souto (2006) explains that the greatest food supply for insects and birds occurs in the rainy season, which may contribute to a greater deposition of parts of dead insects and waste, the main components of this fraction. Although the fraction is less abundant, the components of this fraction are rich in nutrients and energy and, associated with the high degree of fragmentation, may be a more accessible source for decomposers (Proctor, 1987).

The values of $\mathrm{K}$ obtained in the 15 and 30 years old stands show that on the soil a litter quantity is maintained higher than the amount that is produced annually by the vegetation, indicating, therefore, that the utilization of the litter is relatively slow when compared to the 50 years old stand.

In Caatinga studies, the $\mathrm{K}$ values range between 0.71 and 1.25 . The values greater than 1.00 are obtained in preserved Caatinga areas (Souto, 2006; Lopes et al., 2009). We stressed that the studies mentioned above were carried out in preserved areas of the Caatinga, in contrast to the remarkable anthropic intervention observed in the present study, which reflects in the variation of the $\mathrm{K}$ value between the areas, indicating that the stage with less intervention the utilization dynamics of the litter is slightly higher.

Golley et al. (1978) affirm that in tropical forests the values of K are generally greater than 1.0 year $^{-1}$, while Andrade (1997) points out that in temperate forests the $\mathrm{K}$ values are generally lower than 1.0 year $^{-1}$. The time of 
renewal of the material that compiles the litter is longer in temperate forests. However, Santana (2005) observed that there is considerable variability between values ranging from 1.1 to 3.3 year $^{-1}$ in tropical forests and 0.4 to 1.4 year $^{-1}$ in temperate forests.

The time required for the decomposition of $50 \%$ and $95 \%$ of the litter in the studied areas indicate that the decomposition is faster in the older stands. Consequently, a fast reutilization of nutrients by the vegetation in this stands. Lopes et al. (2009) obtained slower rate of decomposition, the times required for decomposition of $50 \%$ and 95\% were, respectively, 358 days and 1,544 days, which is similar to the values found in the 15 years stand. Souto (2006) verified values close to those obtained in the 50 years old stand, 229.9 days for decomposition of $50 \%$ and 996.4 days of $95 \%$ in a preserved fragment of Caatinga, which may indicate that the 50 years old stand already has a high degree of recovery of ecosystem processes.

It was concluded that the deposition of the litter showed seasonal characteristics independent of the age of regeneration of the caatinga forest. The largest contribution in the deposited material corresponded to the leaves fraction in all stands age, which shows that leaf litter production is an efficient indicator of the stage of degradation in a caatinga environment.

There was higher litter production and accumulation in the older stands. The older stands presented faster litter decomposition and renew, which evidences a better utilization of litter in the nutrient cycling process and the incorporation of organic matter into the soil. These results show that litter processes are efficient indicators of the stage of degradation in a caatinga ecosystem.

\section{Acknowledgements}

The authors thank the Conselho Nacional de Desenvolvimento Cientifico e Tecnologico (CNPq) for their financial support and research scholarships. We gratefully acknowledge Fazenda Cachoeira de Sao Porfirio owner, where the research was conducted.

\section{References}

Alencar, L. S. (2014). Fitossociologia e levantamento floristico dos estratos herbáceo e arbóreo em estágios sucessionais no Núcleo de Desertificação do Seridó (Unpublished Masters dissertation, Federal University of Campina Grande. Patos, Brazil).

Almeida, E. J., Luizão, F., \& Rodrigues, D. J. (2015). Produção de serrapilheira em florestas intactas e exploradas seletivamente no sul da Amazônia em função da área basal da vegetação e da densidade de plantas. Acta Amazônica, 45(2), 157-166. https://doi.org/10.1590/1809-4392201402543

Alvares, C. A., Stape, J. L., Sentelhas, P. C., Moraes, G., Leonardo, J., \& Sparovek, G. (2013). Köppen's climate classification map for Brazil. Meteorologische Zeitschrift, 22(6), 711-728. https://doi.org/10.1127/ 0941-2948/2013/0507

Alves, A. R., Souto, J. S., Santos, R. V., \& Campos, M. C. C. (2006). Decomposição de resíduos vegetais de espécies da Caatinga, na região de Patos, PB. Revista Brasileira de Ciências Agrárias, 1, 57-63. https://doi.org/10.5039/agraria.v1i1a308

Anderson, J. M., \& Ingram, J. S. I. (1989). Tropical soil biology and fertility: A handbook of methods. Wallingford, OX: CAB International.

Andrade, A. G. (1997). Ciclagem de nutrientes e arquitetura radicular de leguminosas arbóreas de interesse para revegetação de solos degradados e estabilização de encostas (Unpublished doctoral dissertation, Federal Rural University of Rio de Janeiro, Seropédica, Brazil).

Andrade, R. L., Souto, J. S., Souto, P. C., \& Bezerra, D. M. (2008). Deposição de serrapilheira em área de caatinga na RPPN "Fazenda Tamanduá", Santa Terezinha-PB. Revista Caatinga, 21(2), 223-230.

Bauer, D., Santos, E. L., \& Schmitt, J. L. (2016). Avaliação da decomposição de serapilheira em dois fragmentos de Caatinga no Sertão Paraibano. Pesquisas, Botanica, 69, 307-318.

Costa, C. C. A., Dantas, I. M., Camacho, R. G. V., Souza, A. M. \& Silva, N. G. (2007). Produção de serrapilheira na caatinga da floresta nacional do Açú-RN. Revista Brasileira de Biociências, 5, $246-248$. https:/ufrgs.br/seerbio/ojs/index.php/rbb/article/download/273/24

Cunha-Santino, M. B., \& Biachini, I. Jr. (2002). Estequiometria da decomposição aeróbia de galhos, cascas, serapilheira e folhas. In E. L. G. Espíndola, F. F. Mauad, V. Schalch, O. Rocha, N. Felicidade, \& A. C. Rietzler (Eds.), Recursos Hidroenergéticos: Usos, impactos e planejamento integrado (pp. 43-55). São Carlos, SP: Rima. 
Gariglio, M. A., Sampaio, E. V. S. B., Cestaro, L. A., \& Kageyama, P. Y. (2010). Uso sustentável e conservação dos recursos florestais da caatinga. Brasília, DF: Serviço Florestal Brasileiro.

Golley, F. B., Mcguinness, J. T., Clements, R. G., Child, G. I., \& Deuver, M. J. (1978). Ciclagem de minerais em um ecossistema de floresta tropical úmida. São Paulo, SP: EPU-EdUSP.

Holanda, A. C., Feliciano, A. L. P., Freire, F. J., Sousa, F. Q., Freire, S. R. O., \& Alves, A. R. (2017). Aporte de serapilheira e nutrientes em uma área de caatinga. Ciência Florestal, 27(2), 621-633. https://doi.org/ $10.5902 / 1980509827747$

IUSS Working Group WRB. (2006). World reference base for soil resources 2006-A framework for international classification, correlation and communication. Rome, IT: Food and Agriculture Organization of the United Nations.

Leitão-Filho, H. F., Pagano, S. N., Cesar, O., Timoni, J. L., \& Rueda, J. J. (1993). Ecologia da Mata Atlântica em Cubatão (SP). São Paulo, SP: UNESP.

Lopes, J. F. B., Andrade, E. M., Lobato, F. A. O., Palácio, H. A. Q., \& Arraes, F. D. D. (2009). Deposição e decomposição de serrapilheira em área de caatinga. Agro@ambiente On-line, 3(2), 72-79. https://doi.org/ 10.18227/1982-8470ragro.v3i2.252

Luna, R. G., Andrade, A. P., Souto, J. S., \& Luna, J. G. (2017). Deposição de serapilheira em áreas de caatinga sob diferentes densidades de caprinos. Gaia Scientia, 11(1), 171-193. https://doi.org/10.22478/ufpb.1981$1268.2017 \mathrm{v} 11 \mathrm{n} 1.30113$

Martínez-Yrízar, A. (1995). Biomass distribution and primary productivity of tropical dry forests. In S. Bullock, H. Mooney, \& E. Medina (Eds.), Seasonally Dry Tropical Forests (pp. 326-345). Cambridge, UK: Cambridge University Press. https://doi.org/10.1017/CBO9780511753398.013

Nascimento, L. S., Cerqueira, R. M., \& Henderson, B. L. R. (2015). Produção de serapilheira em um fragmento adjacente a uma cava de mineração, Ribeirão Grande, SP. Revista Brasileira de Engenharia Agrícola e Ambiental, 19(9), 892-897. https://doi.org/10.1590/1807-1929/agriambi.v19n9p892-897

Olson, J. S. (1963). Energy storage and the balance of producers and decomposers in ecological systems. Ecology, 44(2), 322-331. https://doi.org/10.2307/1932179

Paraíba. (2006). Plano Estadual de Recursos Hídricos. João Pessoa, PB: Secretaria Estadual de Recursos Hídricos.

Proctor, J. (1987). Ciclagem de nutrientes em florestas secundárias primária e antiga. Geografia Aplicada, 7(2), $135-152$.

Santana, J. A. S. (2005). Estrutura fitossociológica, produção de serapilheira e ciclagem de nutrientes em uma área de Caatinga no Seridó do Rio Grande do Norte (Unpublished doctoral dissertation, Federal University of Paraíba, Areia, Brazil).

Santana, J. A. S., \& Souto, J. S. (2011). Produção de serapilheira na Caatinga da região semi-árida do Rio Grande do Norte, Brasil. IDESIA, 29(2), 87-94. https://doi.org/10.4067/S0718-34292011000200011

Shanks, R. E., \& Olson, J. S. (1961). First year breakdown of leaf litter in Southern Appalachian Forests. Science, 134(3473), 194-195. https://doi.org/10.1126/science.134.3473.194

Souto, P. C. (2006). Acumulação e decomposição de serapilheira e distribuição de organismos edáficos em área de caatinga na Paraiba, Brasil (Unpublished masters dissertation, Federal University of Paraíba, Areia, Brazil).

\section{Copyrights}

Copyright for this article is retained by the author(s), with first publication rights granted to the journal.

This is an open-access article distributed under the terms and conditions of the Creative Commons Attribution license (http://creativecommons.org/licenses/by/4.0/). 